\title{
Studies on the Translocation of Photosynthates in Satsuma Mandarin
}

\author{
II. Effect of Root Environmental Conditions on the Translocation of ${ }^{14} \mathrm{C}$ \\ Kazuomi KADOYA \\ College of Agriculture, Ehime University, Matsuyama
}

\begin{abstract}
Summary
Effects of water stress and $\mathrm{H}$-ion concentration on the rate of translocation of ${ }^{14} \mathrm{C}$ labeled photosynthates in Satsuma mandarin trees were studied.

When the root growth was suppressed, translocation to the remaining plant parts (growing areas) was decreased and more ${ }^{14} \mathrm{C}$ was accumulated in the leaves.

In the plot of $\mathrm{pH} 3.0$ a little decrease in the rate of translocation to fruits was observed, while in the plot of water stress the accumulation of ${ }^{14} \mathrm{C}$ in the juice was heavily decreased.

Water stress caused an increase in total sugar concentration of the juice. It seems likely that this was partly a result of the concentration effect arisen from water stress. However, in this case other factors such as polisacharide metabolism may also play an important role in the process of sugar accumulation in the juice.
\end{abstract}

\section{Introduction}

In the previous paper, it was pointed out that during the early stage of shoot growth, a large amount of ${ }^{14} \mathrm{C}$ was translocated to the developing shoots and fruits. The distribution pattern of ${ }^{14} \mathrm{C}$ within a tree was strongly affected by such developing parts (2).

This paper deals with the effect of some root environmental conditions on the translocation of photosynthates in Satsuma mandarin trees.

\section{H-ion concentration of culture solutions and the distribution of ${ }^{14} \mathrm{C}$}

\section{Materials and methods}

One-year-old Satsuma mandarin trees were grown in sand culture. As was described earlier, ${ }^{14} \mathrm{C}$ was used as a tracer. On August 26, 1969, ${ }^{14} \mathrm{CO}_{2}$ was generated in a feeding chamber and the leaves were exposed to the tracer gas for three hours, from 10:00 AM to 1:00 PM. The activity of ${ }^{14} \mathrm{C}$ used in this experiment was $70 \mu \mathrm{ci}$ per tree. Immediately after ${ }^{14} \mathrm{CO}_{2}$ feeding, $\mathrm{pH}$ of the culture solution was adjusted to 3.0 and 6.8 with $\mathrm{HCl}$ or $\mathrm{NaOH}$. The plot of $\mathrm{pH} 6.8$ is referred to as the control. Samples were collected 72 hours after ${ }^{14} \mathrm{CO}_{2}$ treatment. The procedures of ${ }^{14} \mathrm{C}$ analysis have been described in the previous paper (2).

\section{Results}

Table 1 shows the effect of $\mathrm{H}$-ion concentration on the distribution of ${ }^{14} \mathrm{C}$. Although the dry weight of summer cycle shoots was trivial to that of a whole tree, ${ }^{14} \mathrm{C}$ activity in those shoots was very high. This agreed with the data mentiononed in the previous papar (2).

The percentage of ${ }^{14} \mathrm{C}$ translocated to the roots was 33.5 in the control plot while in the plot of $\mathrm{pH} 3.0$, it was only 22.6. It seems reasonable to assume that the translocation of ${ }^{14} \mathrm{C}$ to the roots may have been affected by unfavorable conditions for root growth. This can be seen not only from the percentage of ${ }^{14} \mathrm{C}$ within a whole tree (Table 1) but also from the total amount of ${ }^{14} \mathrm{C}$ distributed to the underground parts (Table 2).

\section{Effects of water stress and pH of culture solutions on the transloction of ${ }^{14} \mathrm{C}$ in Wase (Early ripening) satsuma mandarin trees.}

\section{Meterials and methods}

Four-year-old trees were used. The experiment consisted of the following treatments: 
Table 1. ${ }^{14} \mathrm{C}$ distribution in one-year-old Wase satsuma trees as affected by $\mathrm{pH}$ of nutrient solutions.

\begin{tabular}{c|c|c|c|c|c|c|c|c}
\hline \hline & $\begin{array}{l}\text { pH of culture } \\
\text { solution }\end{array}$ & Old leaves & $\begin{array}{l}\text { Spring cycle } \\
\text { leaves }\end{array}$ & $\begin{array}{l}\text { Summer cycle } \\
\text { leaves }\end{array}$ & Branches & Stem & $\begin{array}{l}\text { Fibrous } \\
\text { roots }\end{array}$ & $\begin{array}{l}\text { Main } \\
\text { root }\end{array}$ \\
\hline \multirow{2}{*}{ Dry weight* } & 6.8 & 8.9 & 10.7 & 0.4 & 5.9 & 17.3 & $\begin{array}{r}19.5 \\
17.7\end{array}$ & 36.9 \\
& 3.0 & 8.1 & 10.8 & 1.0 & 4.2 & 16.9 & 17.8 \\
\hline \multirow{2}{*}{${ }^{14} C^{* *}$} & 6.8 & 16.1 & 23.7 & 11.8 & 6.5 & 8.1 & 21.6 & 11.9 \\
& 3.0 & 15.3 & 26.3 & 25.6 & 2.9 & 6.8 & 16.1 & 6.5 \\
\hline
\end{tabular}

* Per cent of the entire tree.

** ${ }^{14} \mathrm{C}$ as shown in the percentage of total ${ }^{14} \mathrm{C}$ in the plant.

Table 2. Total ${ }^{14} \mathrm{C}$ activity of plant parts in one-year-old Wase satsuma trees.

\begin{tabular}{l|c|c|c|c|c|c|c|c}
\hline \hline & $\begin{array}{l}\text { pH of culture } \\
\text { Solution }\end{array}$ & O1d leaves & $\begin{array}{l}\text { Spring cycle } \\
\text { leaves }\end{array}$ & $\begin{array}{l}\text { Summer cycle } \\
\text { leaves }\end{array}$ & Branches & Stem & $\begin{array}{l}\text { Fibrous } \\
\text { roots }\end{array}$ & Main root \\
\hline $\begin{array}{l}\text { Dry weight } \\
(\mathrm{g} / \text { tree })\end{array}$ & 6.8 & 6.66 & 8.00 & 0.31 & 4.44 & 12.87 & 14.56 & 27.48 \\
\hline \multirow{2}{*}{${ }^{14} \mathrm{C}(\mu \mathrm{ci} /$ tree $)$} & 3.0 & 7.24 & 9.64 & 0.95 & 3.75 & 15.07 & 15.78 & 36.26 \\
\hline
\end{tabular}

Table 3. ${ }^{14} \mathrm{C}$ distribution in 4 -year-old Wase satsuma trees as affected by $\mathrm{pH}$ and water stress.

\begin{tabular}{c|c|l|c|c|c|c}
\hline \hline \multirow{2}{*}{} & \multicolumn{2}{|c|}{ Treatment } & Fruits & Leaves & Stem \& braches & Roots \\
\cline { 2 - 6 } & pH of culture solution & Moisture & & & & \\
\hline \multirow{3}{*}{ Dry weight* } & 3.0 & High & 21.5 & 19.8 & 28.5 & 29.8 \\
& 6.8 & Stressed** & 26.8 & 19.3 & 24.3 & 29.0 \\
& 6.8 & High & 20.5 & 19.7 & 27.1 & 32.3 \\
\hline \multirow{2}{*}{${ }^{44} \mathrm{C}^{* * *}$} & 3.0 & High & 23.8 & 47.7 & 17.0 & 11.2 \\
& 6.8 & Stressed & 16.8 & 46.9 & 20.7 & 15.2 \\
& 6.8 & High & 23.8 & 37.0 & 15.7 & 23.1 \\
\hline
\end{tabular}

* Per cent of the entire tree.

** Moisture was stressed during the first 24 hours after the ${ }^{14} \mathrm{CO}_{2}$ treatment.

*** ${ }^{14} \mathrm{C}$ as shown in the percentage of total ${ }^{14} \mathrm{C}$ in plant.

Table 4. ${ }^{14} \mathrm{C}$ activity of plant parts in 4-year-old Wase satsuma trees*.

\begin{tabular}{|c|c|c|c|c|c|c|c|c|c|}
\hline \multicolumn{2}{|c|}{ Treatment } & \multirow{2}{*}{ Pee1 } & \multirow{2}{*}{ Juice** } & \multirow{2}{*}{ Leaves } & \multicolumn{2}{|c|}{ Branches } & \multirow{2}{*}{ Stem } & \multirow{2}{*}{$\begin{array}{l}\text { Fibrous } \\
\text { roots }\end{array}$} & \multirow{2}{*}{$\begin{array}{l}\text { Main } \\
\text { root }\end{array}$} \\
\hline $\begin{array}{l}\mathrm{pH} \text { of culture } \\
\text { solution }\end{array}$ & Moisture & & & & small & large & & & \\
\hline 3.0 & High & 0.123 & 0.019 & 0.314 & 0.116 & 0.077 & 0.059 & 0.075 & 0.026 \\
\hline 6.8 & Stressed & 0.114 & 0.007 & 0.300 & 0.147 & 0.113 & 0.083 & 0.119 & 0.022 \\
\hline 6.8 & High & 0.127 & 0.020 & 0.215 & 0.138 & 0.053 & 0.045 & 0.180 & 0.036 \\
\hline
\end{tabular}

* ${ }^{14} \mathrm{C} \mu \mathrm{ci}$ per gram dry weight.

** ${ }^{14} \mathrm{C} \mu \mathrm{ci}$ per $\mathrm{m} l$ juice.

1) Immediately after ${ }^{14} \mathrm{CO}_{2}$ feeding, $\mathrm{pH}$ of the culture solutions was adjusted to 3,0 and the solutions were supplied throughout the experiment; 2) During the first 24 hours, the trees were grown without any water supply. Thereafter, the culture solution having a $\mathrm{pH}$ of 6.8 was supplied; 3 ) The culture solution adjusted to $\mathrm{pH} 6.8$ was supplied from the beginning to the end of the experiment. In all the treatment plots, samples were collected 72 hours after ${ }^{14} \mathrm{CO}_{2}$ feeding and then ${ }^{14} \mathrm{C}$ analysis. was performed.

Results

The distribution of ${ }^{14} \mathrm{C}$ was shown in Table 
3. The translocation of ${ }^{14} \mathrm{C}$ to fruit was not inhibited by high acid conditions. These results-may be confirmed further in Table 4 . However, under the water stressed conditions, ${ }^{14} \mathrm{C}$ activity in the juice was about one third as compared with that of the control.

The distribution of ${ }^{14} \mathrm{C}$ to the roots was decreased in both $\mathrm{pH} 3.0$ and water stressed plots (Table 3 and 4). In the leaves of the control plant the activity of ${ }^{14} \mathrm{C}$ was lowest. This shows that in the control plant the translocation of photosynthates out of leaves was very active.

\section{Effect of water stress under field conditions on moisture and sugar contents in fruits.}

\section{Materials and methods}

It has been reported that under water stressed conditions the sugar contents in the fruits were increased (6). However, the results mentioned above seems contradictory to the generally accepted experiences on the effect of water stress. Thus, it may be significant to clarify the effect of water stress on the sugar concentration of the juice from the viewpoint of the translocation of photosynthates.

For the field investigations, four commercial citrus groves were chosen. Two were located in Matsuyama area, and the other two were in Yawatahama area. In each citrus grove, two treatments were made. In the check plot, furrow irrigation was performed every 10 days from early September to early October. Twenty $\mathrm{mm}$ of water was supplied each time. In the water stressed treatment, however, no irrigation was supplied. Precipitation at Matsuyama and Yawatahama in the autumn of 1969 are shown in Table 6. Each plot consisted of 3 trees. Five fruits per tree were sampled. Varieties and sampling date were shown in Table 5 . Immediately after the sampling, the fresh peel and pulp were weighed, oven dried at $100^{\circ} \mathrm{C}$ and reweighed. Moisture content was calculated from the data obtained. Total sugars in the juice was analyzed by a Somogy-Nelson procedure.

\section{Results}

Fruit growth was decreased with increasing water stress (Table 7). However, the dif-
Table 5. Four citrus groves where fruits were sampled for the analysis of moisture and sugar contents of fruits.

\begin{tabular}{c|c|c|c|c}
\hline $\begin{array}{c}\text { Citrus } \\
\text { grove }\end{array}$ & Location & $\begin{array}{c}\text { Age of } \\
\text { tree (Yr.) }\end{array}$ & Variety & $\begin{array}{l}\text { Sampling } \\
\text { date }\end{array}$ \\
\hline 1 & Matsuyama & 48 & Ikeda & Oct.29,1969 \\
2 & Matsuyama & 15 & Owari & Nov.11,1969 \\
3 & Yawatahama & 8 & Nankan & Nov.20,1969 \\
4 & Yawatahama & 8 & Miyagawa & Nov,20,1969 \\
\hline
\end{tabular}

Table 6. Precipitations at Matsuyama and Yawatahama in the autumn of 1969 .

\begin{tabular}{c|c|c|c}
\hline \hline Location & September & October & November \\
\hline Matsuyama & $16.5 \mathrm{~mm}$ & $41 \mathrm{~mm}$ & $65 \mathrm{~mm}$ \\
Yawatahama & 17.0 & 74 & 78 \\
\hline
\end{tabular}

ference in fruit weight was not always significant between the treatments..... Moisture content in the pulp and peel was always high in the check plot. On the other hand, sugar contents were decreased with increasing water supply. As for the moisture and sugar contents in the pulp, it can be said that the rate of the increase in the latter is greater than that of the decrease in the former. In order to simplify the explanation about the 'concentration effect' of moisture, the following approximate estimation may conveniently. be used. It is exemplified in fruits from the first grove shown in Table 7 . In the control plot, moisture content of pulp per fruit is estimated as follows:

$$
64.37 \times 88.68 \times \frac{1}{100}=57.08 \mathrm{~g}
$$

Then if the juice content is assumed to be equal to the moisture content, an approximate estimate of sugar content of the juice per fruit may be

$$
8.85 \times \frac{1}{100} \times 57.08=5.05 \mathrm{~g}
$$

Further, if it can be assumed here that in the water stressed plot a moisture loss occured without any changes of sugar metabolism, water content in the pulp is

$$
64.37 \times 85.04 \times \frac{1}{100}=54.74 \mathrm{~g}
$$

where the value 85 indicates the water content in per cent of the pulp of water stressed fruit. Thus the total sugar content per 100 $\mathrm{m} l$ of juice can be estimated as follows: 
Table 7. Effect of water stress on the sugar contents in Satsuma mandarin fruits.

\begin{tabular}{|c|c|c|c|c|c|}
\hline & \multirow{2}{*}{ Treatment } & \multicolumn{4}{|c|}{ Citrus grove* } \\
\hline & & 1 & 2 & 3 & 4 \\
\hline $\begin{array}{l}\text { Pulp } \\
\text { weight }\end{array}$ & $\begin{array}{l}\text { Control } \\
\text { Stressed } \\
\text { Significance }\end{array}$ & $\begin{array}{l}64.37 \\
60.63 \\
\text { NS }\end{array}$ & $\begin{array}{l}91.91 \\
77.83 \\
\text { NS }\end{array}$ & $\begin{array}{l}93.21 \\
59.93 \\
10.55\end{array}$ & $\begin{array}{r}100.87 \\
91.79 \\
8.81\end{array}$ \\
\hline $\begin{array}{l}\text { Pulp } \\
\text { moisture (per cent) } \\
\text { content }\end{array}$ & $\begin{array}{l}\text { Control } \\
\text { Stressed } \\
\text { Significance }\end{array}$ & $\begin{array}{r}88.68 \\
85.04 \\
0.35\end{array}$ & $\begin{array}{r}87.62 \\
84.99 \\
0.59\end{array}$ & $\begin{array}{r}87.42 \\
84.26 \\
0.79\end{array}$ & $\begin{array}{r}88.70 \\
83.80 \\
0.86\end{array}$ \\
\hline $\begin{array}{l}\text { Peel } \\
\text { moisture (per cent) } \\
\text { content }\end{array}$ & $\begin{array}{l}\text { Control } \\
\text { Stressed } \\
\text { Significance }\end{array}$ & $\begin{array}{r}73.77 \\
69.95 \\
1.29\end{array}$ & $\begin{array}{r}73.00 \\
70.80 \\
1.75\end{array}$ & $\begin{array}{r}73.17 \\
67.43 \\
3.14\end{array}$ & $\begin{array}{r}74.75 \\
68.02 \\
1.04\end{array}$ \\
\hline $\begin{array}{l}\text { Total** } \\
\text { sugar } \\
\text { content }\end{array}$ & $\begin{array}{l}\text { Control } \\
\text { Stressed } \\
\text { Significance }\end{array}$ & $\begin{array}{l}8.85 \\
9.54 \\
0.65\end{array}$ & $\begin{array}{r}9.19 \\
11.93 \\
0.90\end{array}$ & $\begin{array}{r}10.34 \\
12.12 \\
0.91\end{array}$ & $\begin{array}{r}9.44 \\
13.42 \\
0.57\end{array}$ \\
\hline
\end{tabular}

* Same as in Table 5.

** Grams per $100 \mathrm{~m} l$ juice.

$$
\frac{5.05}{54.74} \times 100=9.22 \mathrm{~g}
$$

An increase from 8.85 to 9.22 may imply a concentration effect of moisture.' It is important, however, that in the water stressed plot the sugar content was 9.54 wich is somewhat higher than the calculated value 9.22. Similar results were obtained in the fruit from the other groves shown in Table 7 .

\section{Discussion}

In the previous paper, it was pointed out that normally developing fruits and shoots had the capacity as strong sinks and affected the distribution pattern of ${ }^{14} \mathrm{C}$ within the tree.

The purposes of the present investigation were to clarify the effect of root environmental conditions on the distribution of photosynthates among plant parts. As was mentioned previously, an application of culture solutions with high acidity caused a decrese of ${ }^{14} \mathrm{C}$ translocation to the roots. This may be intimately related to the suppressing effect of the solution on the root growth. When a developing plant part was suppressed or injured, it may become weak as a sink. As for the translocation to the shoots and fruits, a considerable amount of ${ }^{14} \mathrm{C}$ was translocated even in the plot of $\mathrm{pH} 3,0$. In the water stressed plot, however, the translocation was heavily depressed.

When the sugar concentration of the juice increases, the two possibilities can be expected as follows;

1) As the water supply decreases, the juice is concentrated so that the sugar concentration increases even in the case where no change in the total amount of sugars of the juice results.

2) The absolute increase in the translocation of photosynthates to fruit occurs.

As shown in Table 7, it is true that moisture content was low in the water stressed plot. Considering the fact that the rate of the increase in sugar concentration is greater than that of the concentration effect of moisture in the juice, the first assumption is not enough to explain the mechanism of sugar accumulation in the juice. Thus, the second factor mentioned above must be considered as a possible mechanism. However, the data obtained in this experiment was not the case. The result agrees with that of Possingam et al.(5). They noticed that a water stress of the type in which no visual symptoms were displayed completely inhibited the translocation of photosynthates. THOMPSON et al.(8) pointed out that the rate of photosynthesis was decreased with decreasing soil moisture or relative humidity and watering the plant 
caused an immediate increase in photosynthetic rate. Suzuni et al. also noticed that a reduction in soil moisture resulted in a decreas ein the rate of apparent photosynthesis (7). KRIEdemann et al.(3) stated that above $20^{\circ} \mathrm{C}$ of leaf temperature the rate of photosynthesis increased with increasing relative humidity. From these results, it may be safe to say that there is no room to support the second factor.

PLAUT et al.(4) reported that the amount of ${ }^{14} \mathrm{C}$ which moved out of the leaf was much reduced by water stress, but the concentration of ethanol-soluble ${ }^{14} \mathrm{C}$ in the lower parts of stressed plants eventually surpassed that of the control plants. They posturated that this, at least, was due partly to the superior rate of synthesis of ${ }^{14} \mathrm{C}$-sucrose into enthanolinsoluble compounds in the controls.

Hiller et al.(1) noticed that using a unicellular alga, Chlorella pyrenoidosa, water deficit reduced the incorporation of ${ }^{14} \mathrm{C}$-glucose into methanol insoluble compounds, whereas it increased the incorporation of ${ }^{14} \mathrm{C}$ into sucrose. URsino et al.(9) also pointed out that a more rapid conversion of translocated materials into the ethanol-insoluble form occurred in plants grown under higher soil moisture conditions. These reports show consistently that under water deficient conditions the translocation of photosynthates into sinks become inactive and at the same time the transformation to polysacharides is also depressed so that the ratio of alcohol-soluble fraction to the total translocated sugars increases.

Turning now to the fruits which have been grown under water stressed conditions, it seems reasonable to assume that not only a concentration effect of moisture but also a suppression of polysacharide synthesis resulted in an increase of sugar content in the pulp.

\section{Acknowledgement}

The auther would like to acknowledge the continuing guidance and encouragement of Dr.K. Matsumoto. Thanks are also due to Professor O. TAKECHI and Assistant Professor
T.HASEBA, the Laboratory for Atomic Sciences, Ehime University, for use of the radio tracer facilities.

\section{Literature cited}

1. Hiller, R. G., and H. Greenway. 1968. Effects of low water potentials on some aspects of carbohydrate metabolism in Chlorella pyrenoidosa. Planta. $78: 49-59$.

2. KADOYA, K., and H. TANAKA. 1972. Studies on the translocation of photosynthates in Satsuma mandarin. I. Effect of summer cycle shoot and bearing fruit on the translocation and distribution of ${ }^{14} \mathrm{C}$. J. Japan Soc. Hort. Sci. $41: 23-28.1972$.

3. KRIEDEMANN, P.E. 1968. Some photosynthetic characteristics of citrus leaves. Aust. J. Biol. Sci. 21 : 895-905.

4. Plaut, Z., and L. Reinhold. 1965. The effect of water stress on $\left[{ }^{14} \mathrm{C}\right]$ sucrose transport in bean plants. Aust. J. biol. Sci. 18 : 1143-55.

5. Possingham, J. V., and P.E. KRIEdEMANN. 1969. Environmental effects on the formation and distribution of photosynthetic assimilates in citrus. Proc. First Internat. Citrus Symposium. $1: 325-332$.

6. SAKAmoto, T., and S. OKUCHi. 1968. Effects of rainfall on soluble solids and acid in Satsuma oranges. Japan. Soc. Hort. Sci. $37: 212-220$. (In Japanese).

7. SuzUKi, T., M. KANEKo, and H. TORIKATA. 1969. Studies on the water balance in Satsuma orange trees. II. On the estimation methods of water saturation deficit (W.S.D.) of leaves and the effects of soil moisture and fertilizer supply on the W.S. D. and the apparent photosynthetic rate of leaves. J. Japan., Soc. Hort. Sci. $38: 1-8$. (In Japanese).

8. THOMPSON, C.R., L.H.STOLZY, and O.C. TAYLOR. 1965. Effect of soil suction, relative humidity and temperature on apparent photosynthesis and transpiration of rough lemon (Citrus jambhiri). Proc. Amer. Soc. Hort. Sci. 87 : 168-175.

9. URsino, D. J., and G.KRotKov. 1968. The effect of water stress on the translocation of recent photosynthate to the roots of young plants of Pinus strobus. Can. J. Bot. 46 : 13271329. 
温州ミカンの光合成産物の転流柇よび分配に関する研究（第 2 報）

根の生育環境の相違が ${ }^{14} \mathrm{C}$ の転流に及ぼす影響

門屋 一 臣

(愛媛大学農学部)

摘 要

1. 砂耕栽培の 1 年生温州を供試し, 水素イオン濃度 および断水処理により, 根の生育環境を变兄て, 光合成 産物の転流のよらすを ${ }^{14} \mathrm{C} を$ 使つて，追跡した．

2. 根の生長を抑制すると，光合成産物は，葉にとぞ まる量が多くなり，果実や新しょら拉よび根に対する転 流が悪くなつた。 $\mathrm{pH} 3.0$ 区で，水分供給が十分にある 状態では，果実や新しようへの転流が，少し押えられた

にすぎなからたが，24時間の断水処理をした場合には， 果実への転流が著しく押兄られた。

3. 乾燥下で生長した果実の糖度は高いが，その原因 を, 水分の物理的濃縮のみに帰するには無理があり，上 記の結果とも合わせて，果実内での糖の代謝が乾燥下で は変わつてくる可能性が指摘された。 